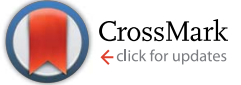

Cite this: J. Mater. Chem. A, 2015, 3, 19061

\section{A gamma fluorinated ether as an additive for enhanced oxygen activity in $\mathrm{Li}-\mathrm{O}_{2}$ batteries $\uparrow$}

\begin{abstract}
Olivia Wijaya, ${ }^{a}$ Pascal Hartmann, ${ }^{\text {b }}$ Reza Younesi, ${ }^{c}$ Iulius I. E. Markovits, ${ }^{d}$ Ali Rinaldi, ${ }^{a}$ Jürgen Janek ${ }^{\mathrm{b}}$ and Rachid Yazami*d

Perfluorocarbons (PFCs) are known for their high $\mathrm{O}_{2}$ solubility and have been investigated as additives in Li$\mathrm{O}_{2}$ cells to enhance the cathode performance. However, the immiscibility of PFCs with organic solvents remains the main issue to be addressed as it hinders PFC practical application in $\mathrm{Li}-\mathrm{O}_{2}$ cells. Furthermore, the effect of PFC additives on the $\mathrm{O}_{2}$ mass transport properties in the catholyte and their stability has not been thoroughly investigated. In this study, we investigated the properties of 1,1,1,2,2,3,3,4,4-nonafluoro-6-propoxyhexane (TE4), a gamma fluorinated ether, and found it to be miscible with tetraglyme (TEGDME), a solvent commonly used in $\mathrm{Li}-\mathrm{O}_{2}$ cells. The results show that with the TE4 additive up to 4 times higher $\mathrm{O}_{2}$ solubility and up to 2 times higher $\mathrm{O}_{2}$ diffusibility can be achieved. With 20 vol\% TE4 addition, the discharge capacity increased about 10 times at a high discharge rate of $400 \mathrm{~mA} \mathrm{gc}_{\mathrm{c}}^{-1}$, corresponding to about $0.4 \mathrm{~mA} \mathrm{~cm}{ }^{-2}$. The chemical stability of TE4 after $\mathrm{Li}-\mathrm{O}_{2}$ cell discharge is investigated using ${ }^{1} \mathrm{H}$ and ${ }^{19} \mathrm{~F} \mathrm{NMR}$, and the TE4 signal is retained after discharge. FTIR and XPS measurements indicate the presence of $\mathrm{Li}_{2} \mathrm{O}_{2}$ as a discharged product, together with side products from the parasitic reactions of LiTFSI salt and TEGDME.
\end{abstract}

Received 11th May 2015

Accepted 7th August 2015

DOI: $10.1039 / \mathrm{c} 5$ ta03439f

www.rsc.org/MaterialsA corresponds to a Bunsen coefficient of $\alpha=0.553$. Read et al. ${ }^{16}$ found a lower Bunsen coefficient of $\alpha=0.0993$ in TEGDME.

The beneficial effect of PFC additives on metal- $\mathrm{O}_{2}$ battery cell performance enhancement has been reported in the literature. In pioneering work submitted to a US patent, Yazami showed an increase of the open-circuit voltage in cells with PFC additives in aqueous electrolytes. ${ }^{17}$ This increase necessarily means that the fluorocarbon additive influences the cell reaction. Later, Balaish et al. ${ }^{\mathbf{1 1 8}}$ and Zhang et al. ${ }^{2}$ reported an increase in the discharge capacity of $\mathrm{Li}-\mathrm{O}_{2}$ battery cells with PFC and partially fluorinated compound additives, respectively. Further, Wang et al. found an increase in the current density during $\mathrm{O}_{2}$ reduction by dispersing perfluorotributylamine in propylene carbonate solvent. ${ }^{4}$ A recent study by Nishikami et al. ${ }^{5}$ showed around 1.5 times capacity increase when dissolving $60 \mathrm{wt} \%$ perfluorohexyl bromide with lithium perfluorooctane sulfonate in tetraglyme. We also reported an enhanced current and discharge capacity with 1-methoxyheptafluoropropane additive in DME and TEGDME based battery electrolytes with a rotating ring disk electrode (RRDE) and a $\mathrm{Li}-\mathrm{O}_{2}$ cell. ${ }^{3}$

The limited miscibility of PFCs in organic solvents is one of the main issues in $\mathrm{Li}-\mathrm{O}_{2}$ cell application. One proposed strategy to overcome this issue is a dispersion of the liquid medium. ${ }^{4}$ However, this approach does not meet the long term stability requirement of the two-phase liquid/liquid dispersion. The other strategy we have pursued is to use PFCs with a lower degree of fluorination as they may provide a good tradeoff between solubility in ethers and $\mathrm{O}_{2}$ dissolution capability. ${ }^{3}$
${ }^{b}$ Institute of Physical Chemistry, Justus-Liebig-Universität Gießen, Heinrich-Buff-Ring 58, 35392 Gießen, Germany

${ }^{c}$ Department of Chemistry-Ångström Laboratory, Uppsala University, Box 538, SE-751 21 Uppsala, Sweden

${ }^{d}$ Energy Research Institute at Nanyang Technological University, 1 CleanTech Loop, \#06-04 CleanTech One, Singapore 637141.E-mail: rachid@pmail.ntu.edu.sg

$\dagger$ Electronic supplementary information (ESI) available. See DOI: $10.1039 / \mathrm{c} 5 \mathrm{ta0} 03439 \mathrm{f}$ 


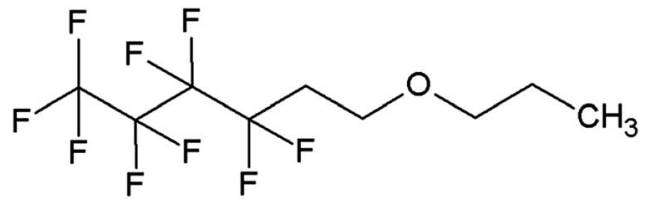

Fig. 1 Molecular structure of 1,1,1,2,2,3,3,4,4-nonafluoro-6-propoxyhexane (TE4).

Another important requirement for PFC additives is good chemical stability in the $\mathrm{Li}-\mathrm{O}_{2}$ cell environment. In fact, superoxide radicals are reported to form in the course of $\mathrm{O}_{2}$ reduction and should account for the instability of solvents commonly used in $\mathrm{Li}-\mathrm{O}_{2}$ batteries, including carbonates and glymes. ${ }^{19-26}$ Recently, we reported on the plausible instability of 1-methoxyheptafluoropropane by using a RRDE and cyclic voltammetry. ${ }^{3}$

In this work, we investigated a gamma-fluorinated ether, 1,1,1,2,2,3,3,4,4-nonafluoro-6-propoxyhexane (TE4) (Fig. 1), as an additive in $\mathrm{Li}-\mathrm{O}_{2}$ batteries. This compound is expected to have greater stability toward the superoxide radicals compared to 1-methoxyheptafluoropropane (an alpha-fluorinated ether) as predicted by the DFT calculation. ${ }^{27}$ The $\mathrm{O}_{2}$ solubility of this compound is also expected to be high $\left(47.76 \mathrm{~cm}^{3} / 100 \mathrm{ml}\right)$ by the calculation developed by Lawson et al. ${ }^{28}$ Furthermore, TE4 is miscible with TEGDME and lithium up to a considerable amount ( $\sim 20 \mathrm{vol} \%)$. Therefore, the issue of dispersion instability and appropriate surfactant could be avoided. The $\mathrm{O}_{2}$ uptake in pure TE4 and TE4 solutions in tetraglyme of various concentrations is measured here. We show the beneficial effects of the TE4 additive on the discharge capacity and on the rate capability in $\mathrm{Li}-\mathrm{O}_{2}$ cells. The stability of the TE4 upon discharge is investigated using NMR spectroscopy. The discharged products are investigated using XPS and FTIR spectroscopy.

\section{Experimental section}

\section{Electrolyte preparation}

TEGDME was purchased from Sigma-Aldrich and distilled prior to use to remove impurities. The solvent is further dried over $3 \AA$ molecular sieves. 99.5\% LiTFSI from Solvay was dried at $60{ }^{\circ} \mathrm{C}$ under 10-3 mbar vacuum for 3 days. 1,1,1,2,2,3,3,4,4-Nonafluoro6-propoxyhexane (HFE-TE4-O-C3), >99\%, (TA4) was obtained from Fluoryx Inc. Its structure is presented in Fig. 1. TE4 is dried over $3 \AA$ molecular sieves in an argon filled glovebox. The electrolyte mixture is prepared inside the argon glovebox with $<1$ ppm $\mathrm{H}_{2} \mathrm{O}$ and $\mathrm{O}_{2}$. The electrolyte water content is analyzed by the Karl Fischer titration technique and it is found to be below 20 $\mathrm{ppm}$. The ionic conductivity was measured using a conductivity meter CyberScan Series 600 from Eutech Instruments and found to be $0.6 \mathrm{mS} \mathrm{cm}{ }^{-1}$ for $0.1 \mathrm{M}$ LiTFSI:TEGDME. The ionic conductivity of the electrolytes with the TE4 additive does not differ significantly. The viscosity of TEGDME is $4.05 \mathrm{cP}^{29}$

\section{Cathode fabrication and cell assembly}

The cathodes were prepared by coating a slurry of graphitized carbon black (Sigma-Aldrich) (80 wt\%) with a PTFE binder
(Sigma-Aldrich) (20 wt\%) onto a Celgard 2320 separator. The slurry was prepared by sonicating (Hielscher, UP200S) the carbon and binder in isopropanol for 5 minutes followed by stirring for 30 minutes using a Heidolph Silent Crusher homogenizer at a high speed of $10000 \mathrm{rpm}$. A $14 \mathrm{~mm}$ cathode disk was cut and dried at $90{ }^{\circ} \mathrm{C}$ for 12 hours before being transferred to the glovebox. Stainless steel mesh was utilized as the current collector. The cathodes are 1.5-1.6 mg in weight, $\sim 10 \mu \mathrm{m}$ in thickness and with a carbon loading of $0.97-1.03 \mathrm{mg}$ $\mathrm{cm}^{-2}$. Cells were assembled in an Ar filled glovebox $\left(\mathrm{O}_{2}<1 \mathrm{ppm}\right.$, $\left.\mathrm{H}_{2} \mathrm{O}<1 \mathrm{ppm}\right)$. An additional Celgard separator is placed between the carbon cathode and the lithium metal anode. The discharge experiments were conducted in ECC-Air laboratory cells produced by EL-Cell $\mathrm{GmbH}^{30}$ with a Kel-F O-ring to avoid water permeation into the cell. ${ }^{31} \mathrm{O}_{2}$ was introduced into the cell with a stainless steel tubing for one hour at $0.5 \mathrm{ml} \mathrm{min}^{-1}$ prior to discharge; the cells were discharged using an Arbin Battery Tester.

\section{Physical characterization}

${ }^{1} \mathrm{H}$ and ${ }^{19} \mathrm{~F}$ NMR spectra of the catholyte were recorded before and after discharge to investigate the stability of the additive. The ${ }^{1} \mathrm{H}$ NMR spectra were measured in $\mathrm{CDCl}_{3}$ on an Avance I $400 \mathrm{MHz}$ NMR spectrometer. For the ${ }^{19} \mathrm{~F}$ NMR spectra, the sample was prepared in DMSO-d6 and measured on an Avance $300 \mathrm{MHz}$ NMR spectrometer. XPS measurements were performed on a PHI 5500 spectrometer (Perkin Elmer Physical Electronics) using monochromatized $\mathrm{Al}-\mathrm{K} \alpha$ radiation $(1487 \mathrm{eV})$ and an electron emission angle of $45^{\circ}$. The probing area was approximately $2 \times 4 \mathrm{~mm}^{2}$. All spectra were energy calibrated by using the C-C peak of carbon black at a binding energy of 284.5 eV. The samples were washed with DME to remove the remaining electrolyte solvent and salt. FTIR measurements were performed using a frontier from Perkin Elmer in the reflectance mode using EasiDiffTM accessories. The spectra were transformed using the Kubelka-Munk equation to compensate the differences with the standard spectra. The discharged cathode was washed with DME and mixed with vacuum dried $\mathrm{KBr}$ inside the glovebox to avoid any reaction during sample preparation.

\section{$\mathrm{O}_{2}$ uptake measurements}

The $\mathrm{O}_{2}$ uptake measurements were performed using a cross fitting setup equipped with a PAA-33X absolute pressure sensor (Omega), an $\mathrm{O}_{2}$ reservoir, and a vacuum pump. $5 \mathrm{ml}$ of the electrolyte mixture was placed in a glass flask and degassed by exposing it to vacuum. The details of the setup and experimental procedure can be found in ref. 32. The determination of the Henry constant was done by increasing the $\mathrm{O}_{2}$ partial pressure repeatedly and measuring the pressure drop due to $\mathrm{O}_{2}$ uptake. The diffusion coefficient was measured by using convection free $\mathrm{O}_{2}$ absorption in thin liquid films, and the data were analyzed by using a 1D diffusion model reported by Hou et $a .^{33}$ The pressure decay profile was recorded until a steady state plateau was obtained. 


\section{Result and discussion}

\section{$\mathrm{O}_{2}$ concentration and diffusion coefficient measurements}

Fig. 2 shows the molar concentration of $\mathrm{O}_{2}$ in the TEGDME solvent with varying TE4 additive contents as a function of pressure at room temperature. The Henry constant $\left(\mathrm{H}_{\mathrm{O}_{2}}\right)$ is determined by the linear fit of this plot as in eqn (1). The diffusion of $\mathrm{O}_{2}\left(D_{\mathrm{O}_{2}}\right)$ is measured for the TEGDME solvent, TEGDME with $20 \mathrm{vol} \%$ TE4, and pure TE4 additive. The $\mathrm{O}_{2}$ diffusion profile and the equation model for the fitting can be found in $\mathrm{S} 1 . \dagger$ The results for $\mathrm{O}_{2}$ concentration and diffusion are summarized in Table 1.

$$
C_{\mathrm{O}_{2}}=H_{\mathrm{O}_{2}} \times P_{\mathrm{O}_{2}}
$$

$C_{\mathrm{O}_{2}}: \mathrm{O}_{2}$ concentration, $H_{\mathrm{O}_{2}}$ : Henry's constant, $P_{\mathrm{O}_{2}}: \mathrm{O}_{2}$ pressure

The data clearly show that the pure TE4 additive has about a four times higher Henry constant $H_{\mathrm{O}_{2}}$ compared to pure TEGDME. Addition of $10 \mathrm{vol} \%, 20 \mathrm{vol} \%$, and $60 \mathrm{vol} \%$ TE4 increases $H_{\mathrm{O}_{2}}$ by factors of $1.2,1.5$, and 3 , respectively, compared to TEGDME alone. $H_{\mathrm{O}_{2}}$ increases linearly with the TE4 concentration (Fig. S2 $\dagger$ ). Moreover, the $D_{\mathrm{O}_{2}}$ in the pure TE4 additive is about 2 times higher than that in the TEGDME solvent. However, surprisingly, the $D_{\mathrm{O}_{2}}$ in the $20 \mathrm{vol} \%$ TE4 additive remains unchanged compared to pure TEGDME. The addition of LiTFSI, especially at a low concentration of $0.1 \mathrm{M}$, will not change $H_{\mathrm{O}_{2}}$ significantly, as evidenced from our previous results. ${ }^{32,34}$

We calculated the $\mathrm{O}_{2}$ solubility based on the fluorocarbon chemical structure by using the method developed by Lawson et $a .^{28}$ and compared it with our experimental result. The $\mathrm{O}_{2}$ solubility $\left(\mathrm{cm}^{3} / 100 \mathrm{ml}\right.$ of liquid) at $25{ }^{\circ} \mathrm{C}$ was found to be of 47.76, which is close to our result of $45.45 \pm 0.15$. The details of the calculation can be found in $\mathrm{S} 3 . \dagger$

The main motivation for incorporating fluorinated additives into the metal- $\mathrm{O}_{2}$ battery is the enhancement of $\mathrm{O}_{2}$ concentration and mass transport. However, most of the previous studies either did not quantify the increase in $\mathrm{O}_{2}$ concentration and diffusion coefficient nor did they quantify them beyond using

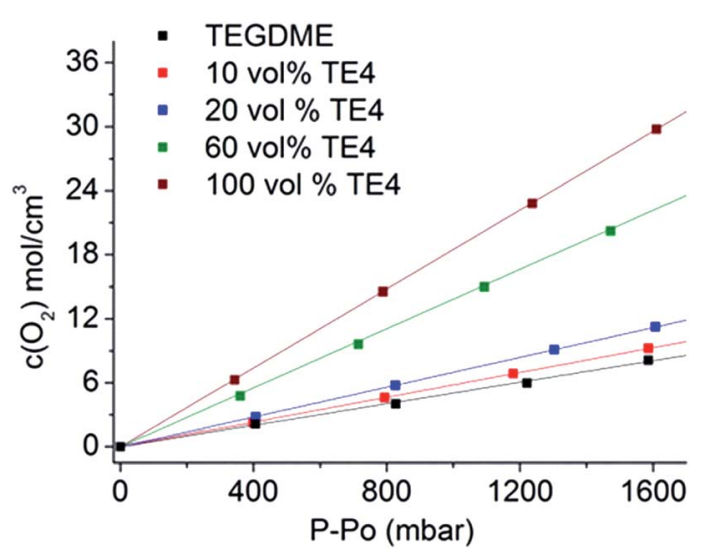

Fig. $2 \mathrm{O}_{2}$ concentration for various TE4 additive concentrations in the TEGDME solvent as a function of $\mathrm{O}_{2}$ pressure. The Henry constant is determined by the linear fit.
Table 1 Henry constant and diffusion coefficient of $\mathrm{O}_{2}$ for TEGDME with different additive concentrations determined from oxygen takeup experiments

\begin{tabular}{lllll}
\hline Solvents & $\begin{array}{l}\text { [TE4 }] \\
(\mathrm{M})\end{array}$ & $\begin{array}{l}\text { Density } \\
\left(\mathrm{g} \mathrm{cm}^{-3}\right)\end{array}$ & $\begin{array}{l}H_{\mathrm{O}_{2}} \\
\left(\mathrm{~mol} \mathrm{~m}^{-3} \mathrm{bar}^{-1}\right)\end{array}$ & $\begin{array}{l}D_{\mathrm{O}_{2}} / 10^{-5} \\
\left(\mathrm{~cm}^{2} \mathrm{~s}^{-1}\right)\end{array}$ \\
\hline TEGDME & 0 & 1.003 & $4.8 \pm 0.2$ & $2.60 \pm 0.03$ \\
$\begin{array}{l}\text { TEGDME + 10 vol\% } \\
\text { TE4 }\end{array}$ & 0.43 & 1.032 & $5.8 \pm 0.2$ & - \\
$\begin{array}{l}\text { TEGDME + 20 vol\% } \\
\text { TE4 }\end{array}$ & 0.86 & 1.180 & $7.0 \pm 0.2$ & $2.62 \pm 0.06$ \\
TEGDME + 60 vol\% & 2.57 & 1.263 & $14.2 \pm 0.4$ & - \\
TE4 & & & & \\
TE4 & - & 1.313 & $18.6 \pm 0.6$ & $5.10 \pm 0.06$ \\
& & & &
\end{tabular}

electrochemical techniques such as Rotating Ring Disk Electrodes (RRDEs). ${ }^{3,4}$ The rotating ring disk electrode has several limitations such as salt precipitation at high fluorocarbon concentration, high volume of sample, and also problematic data interpretation due to the probability of electrolyte/additive instability in the $\mathrm{O}_{2}$ environment. Therefore, we used pressure dynamic measurements to quantify $\mathrm{O}_{2}$ concentration and the diffusion of the fluorocarbon additive. This approach requires a relatively low amount of sample and provides clear data interpretation since only $\mathrm{O}_{2}$ gas is utilized for the measurements. ${ }^{32}$

\section{Discharge at various rates}

The maximum amount of miscible TE4 in 0.1 M LiTFSI:TEGDME is $20 \mathrm{vol} \%(0.86 \mathrm{M})$. Above $20 \mathrm{vol} \%$ TE4 concentration, LiTFSI will precipitate. Electrolyte mixtures with different TE4 additive concentrations (0-20 vol\%) were therefore tested during discharge at various rates.

Fig. 3a shows that at $100 \mathrm{~mA} \mathrm{~g}_{\mathrm{C}}{ }^{-1}$ (about $0.1 \mathrm{~mA} \mathrm{~cm}^{-2}$ ), the $\mathrm{Li}-\mathrm{O}_{2}$ cell with $0.1 \mathrm{M}$ LiTFSI:TEGDME electrolyte yields $375 \mathrm{~mA}$ $\mathrm{h} \mathrm{g}_{\mathrm{C}}{ }^{-1}$ capacity with a voltage plateau of $\sim 2.55 \mathrm{~V}$. The capacity increases by $\sim 25 \mathrm{~mA} \mathrm{~h} \mathrm{~g}{ }_{\mathrm{C}}{ }^{-1}$ and $\sim 50 \mathrm{~mA} \mathrm{~h} \mathrm{~g}_{\mathrm{C}}{ }^{-1}$ by adding 10 vol\% and 20 vol\% TE4, respectively. However, there is no unequivocal change in discharge voltage observed.

Fig. $3 \mathrm{~b}$ shows the discharge profile at $200 \mathrm{~mA} \mathrm{~g}_{\mathrm{C}}{ }^{-1}$ (about 0.2 $\mathrm{mA} \mathrm{cm}{ }^{-2}$ ) current rate. The discharge capacity of the cell with $0.1 \mathrm{M}$ LiTFSI:TEGDME electrolyte decreases to $300 \mathrm{~mA} \mathrm{~h} \mathrm{~g}{ }_{\mathrm{C}}{ }^{-1}$ and the discharge voltage decreases to $2.42 \mathrm{~V}$. However, the discharge voltage increased to $\sim 70 \mathrm{mV}$ with the 20 vol\% TE4 additive as compared to the TE4 free electrolyte. Fig. 3c displays the discharge profile at a high current rate of $400 \mathrm{~mA} \mathrm{~g}_{\mathrm{C}}{ }^{-1}$ (about $0.4 \mathrm{~mA} \mathrm{~cm}^{-2}$ ). The TE4 free cell yielded a low capacity of $25 \mathrm{~mA} \mathrm{~h} \mathrm{~g}_{\mathrm{C}}{ }^{-1}$. The latter increased to $90 \mathrm{~mA} \mathrm{~h} \mathrm{~g}{ }_{\mathrm{C}}{ }^{-1}$ and $225 \mathrm{~mA}$ $\mathrm{h} \mathrm{g}_{\mathrm{C}}{ }^{-1}$ in electrolytes with $10 \mathrm{vol} \%$ and $20 \mathrm{vol} \% \mathrm{TE} 4$, which is about 3.5 times and about 10 times higher, respectively.

The effect of the TE4 additive is more paramount at a high discharge rate, where the $\mathrm{O}_{2}$ supply is critical. Our improved discharge performance data are in agreement with those of Read et al. owing to the enhanced $\mathrm{O}_{2}$ solubility. ${ }^{2}$ Read et al. used $\mathrm{PC}$ as a solvent ${ }^{2}$ which is unstable under $\mathrm{O}_{2}$ reduction and did not address the stability issue of the PFC additive. ${ }^{35}$ In this work, the TEGDME is used due to its higher stability toward 

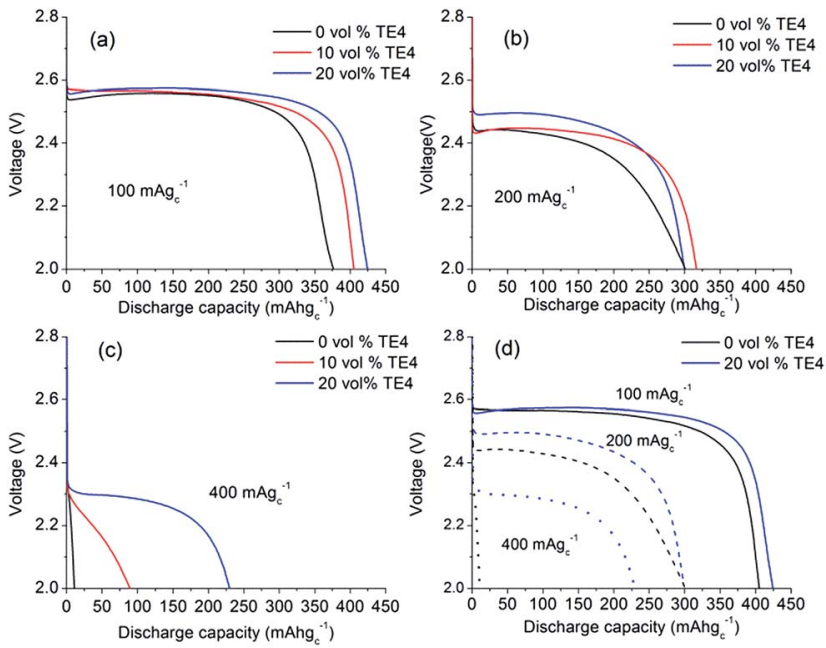

Fig. 3 Galvanostatic discharge profiles of $\mathrm{Li}-\mathrm{O}_{2}$ cells at current densities of (a) $100 \mathrm{~mA} \mathrm{gc}^{-1}$ (about $0.1 \mathrm{~mA} \mathrm{~cm}^{-2}$ ), (b) $200 \mathrm{~mA} \mathrm{gc}^{-1}$ (about $0.2 \mathrm{~mA} \mathrm{~cm}^{-2}$ ), and (c) $400 \mathrm{~mA} \mathrm{gc}^{-1}$ (about $0.4 \mathrm{~mA} \mathrm{~cm}^{-2}$ ) with $0.1 \mathrm{M}$ LiTFSI in TEGDME containing 0,10 , and 20 vol\% TE4 additive. (d) A summary of the effect of the TE4 additive by comparing the electrolyte with 0 and 20 vol\% TE4 at various discharge rates.

superoxides compared to PC. ${ }^{36}$ As discussed in the next section, TE4 is relatively stable towards oxidation, which results in good performance during the first discharge in the $\mathrm{Li}-\mathrm{O}_{2}$ battery. Fig. 4 shows the cycle performance of the $\mathrm{Li}-\mathrm{O}_{2}$ cell with $0.1 \mathrm{M}$ LiTFSI:TEGDME with and without the addition of the TE4 additive. We found out that the cell with the TE4 additive has a longer cycle life than that with the TEGDME only additive. At the $50^{\text {th }}$ cycle, the cell with the TE4 additive can still be discharged up to $100 \mathrm{~mA} \mathrm{~h} \mathrm{~g}_{\mathrm{C}}{ }^{-1}$ while the cell without the additive can only be discharged up to $76 \mathrm{~mA} \mathrm{~h} \mathrm{~g}_{\mathrm{C}}{ }^{-1}$. The charge voltage is also consistently slightly lower for the cell with the TE4 additive. Nevertheless, the exact mechanism of discharge and charge for the cell with and without the TE4 additive is beyond the scope of this work.

\section{Stability of the TE4 additive}

The chemical stability of the fluorocarbon additive in $\mathrm{Li}-\mathrm{O}_{2}$ cells has not been investigated although it is a pre-requisite for battery application.

In this section, we will first evaluate the electrochemical window of the electrolyte with the TE4 additive in an argon environment. Subsequently, the stability of the TE4 additive is evaluated using ${ }^{1} \mathrm{H}$ NMR and ${ }^{19}$ F NMR for the electrolyte before and after discharge.

Fig. 5 shows the cyclic voltammogram (CV) in argon for the cell with and without the TE4 additive in the electrolyte at $1 \mathrm{mV} \mathrm{s}^{-1}$ from $2.8 \mathrm{~V}$ to a lower potential of $2 \mathrm{~V}$ or $1.5 \mathrm{~V}$ and then to $4.5 \mathrm{~V}$. The CV profiles of cells with the TE4 additive coincide with the CV profile of the cell with only 0.1 M LiTFSI:TEGDME within 2-4.5 $\mathrm{V}$ and $1.5-4.5 \mathrm{~V}$. There is no additional reduction or oxidation peak observed. This signifies that the TE4 additive is electrochemically stable within the above mentioned voltage range. This is especially important since we tested the $\mathrm{Li}-\mathrm{O}_{2}$ cell

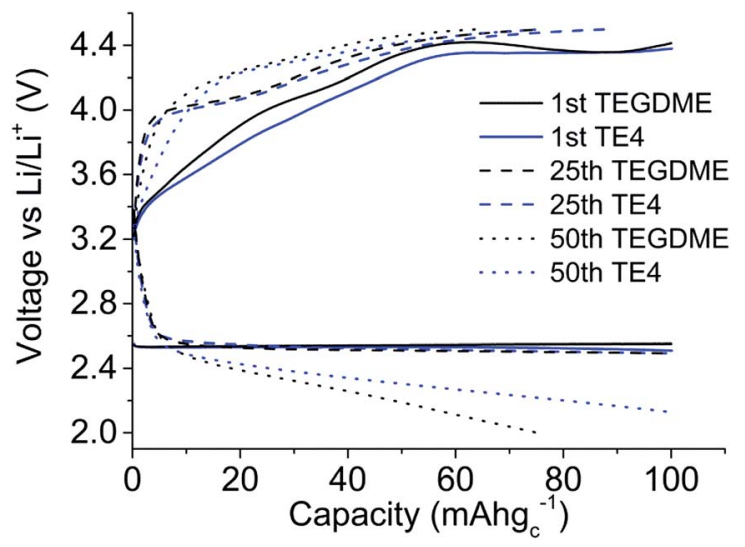

Fig. $41^{\text {st }}$ (solid line), $25^{\text {th }}$ (dashed line) and $50^{\text {th }}$ (dotted line) charge and discharge cycle profiles for the $\mathrm{Li}-\mathrm{O}_{2}$ cell using $0.1 \mathrm{M}$ LiTFSI: TEGDME (black) and 0.1 M LiTFSI:TEGDME + 20 vol\% TE4 additives (blue). The cells were galvanostatically discharged at $100 \mathrm{~mA} \mathrm{gc}^{-1}$ up to $100 \mathrm{~mA} \mathrm{~h} \mathrm{gc}^{-1}$ or $2 \mathrm{~V}$ and charged at $100 \mathrm{~mA} \mathrm{gc}^{-1}$ up to $100 \mathrm{~mA} \mathrm{~h}$ $\mathrm{gc}_{\mathrm{c}}^{-1}$ or $4.5 \mathrm{~V}$, whichever limit reached earlier.

within 2-4.5 V. The ${ }^{1} \mathrm{H}$ and ${ }^{19} \mathrm{~F}$ NMR spectra recorded on pure TE4 are in agreement with the literature (the description of the spectra can be found in S6 $\dagger$ ). As shown in Fig. 6, the ${ }^{1} \mathrm{H}$ NMR spectra after discharge is quasi-identical to the pure TE4 one, denoting a high stability. This is further evidenced by ${ }^{19} \mathrm{~F}-\mathrm{NMR}$ data displayed in Fig. 7.

All signals can be assigned to TE4 with the exception of the one at $\delta=-78.93$ ppm corresponding to LiTFSI. ${ }^{37}$ However, the integral peak ratio of $\mathrm{CF}_{3}(-80.94 \mathrm{ppm})$ : LiTFSI $(-78.93 \mathrm{ppm})$ increased after discharge from $1: 0.2$ to $1: 0.3$. Therefore, TE4 shows considerably higher stability during $\mathrm{O}_{2}$ reduction when compared to the 1-methoxyheptafluropropane additive we reported on. ${ }^{3}$ In fact, the ${ }^{1} \mathrm{H}$ and ${ }^{19} \mathrm{~F}$ signals from 1-methoxyheptafluoropropane completely disappeared after discharge (S4 and $\mathbf{S} 5 \dagger$ ) as a sign of instability.

The increased stability is attributed to the synergistic effect of the two alkyl chains besides the ether group in TE4.

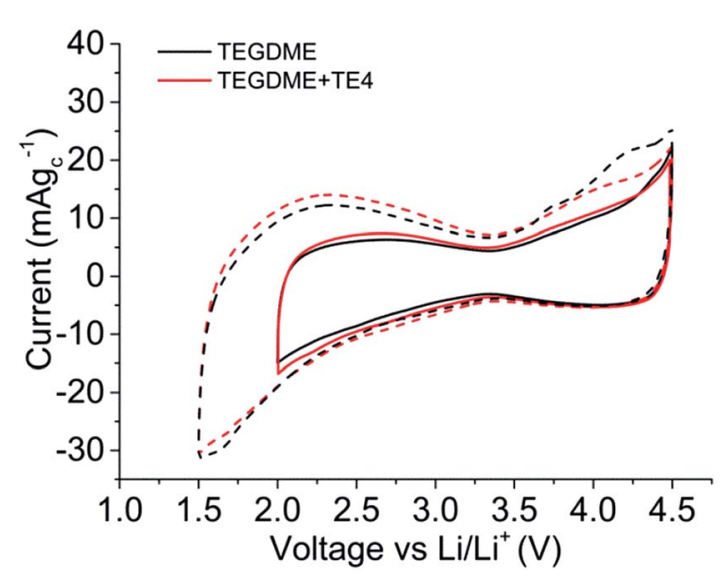

Fig. 5 Electrochemical stability window of $0.1 \mathrm{M}$ LiTFSI:TEGDME (black) and 0.1 M LiTFSI:TEGDME + 20 vol\% TE4 (red) within potential windows of $2 \mathrm{~V}$ to $4.5 \mathrm{~V}$ (solid line) and $1.5 \mathrm{~V}$ to $4.5 \mathrm{~V}$ (dashed line) $\mathrm{vs}$. Li/ $\mathrm{Li}^{+}$. 


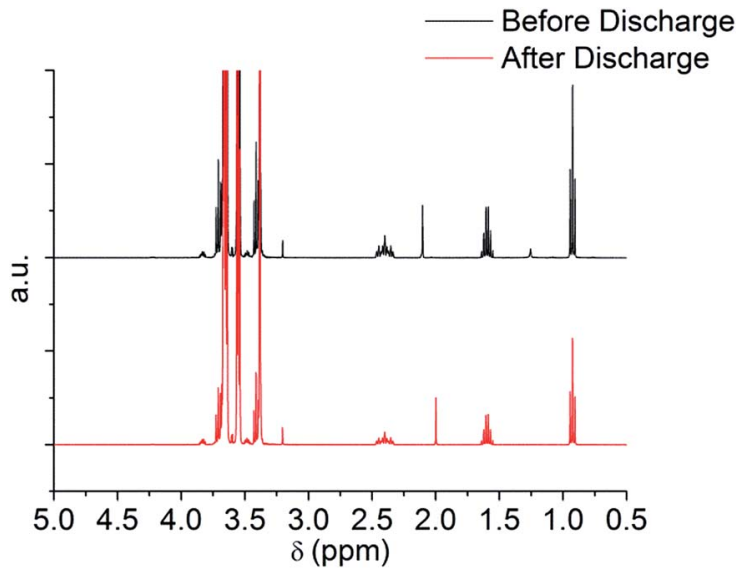

Fig. $6{ }^{1} \mathrm{H}$ NMR before and after discharge at $100 \mathrm{~mA} \mathrm{gc}^{-1}$ to $2 \mathrm{~V}$ of 0.1 M LiTFSI:TEGDME + 20 vol\% TE4.

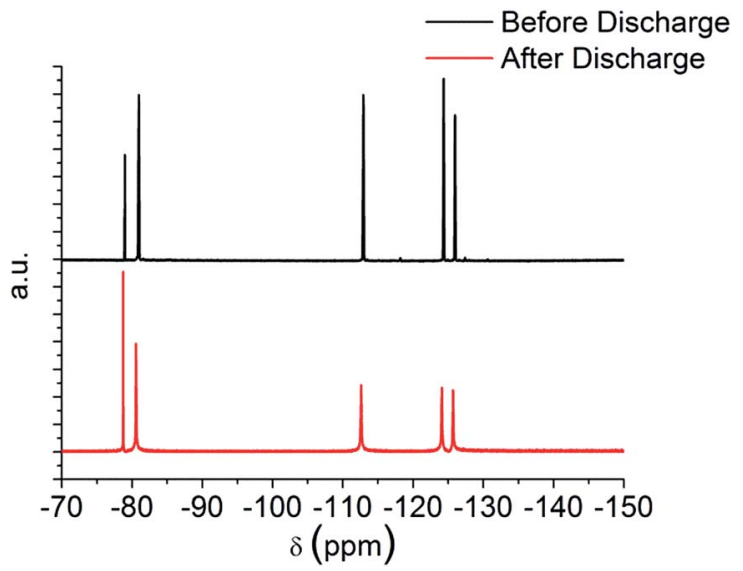

Fig. $7{ }^{19} \mathrm{~F}$ NMR before and after discharge at $100 \mathrm{~mA} \mathrm{gc}^{-1}$ to $2 \mathrm{~V}$ of 0.1 M LITFSI:TEGDME + 20 vol\% TE4.

Theoretical calculations have shown that with fluorination a decreased susceptibility of the $\mathrm{CF}_{2}-\mathrm{O}$ towards an attack by $\mathrm{O}_{2}{ }^{-}$ is expected. However, the fluorination leads to a decreased reaction barrier for an attack to the neighboring bond, i.e. $\mathrm{CH}_{3}-$ O for 1-methoxyheptafluroropropane and therefore an increased instability in the presence of superoxides. ${ }^{20}$ The ethylene bridge in TE4 prevents this destabilization by balancing the electron deficiency created by the fluorinated alkyl group and helps prevent an attack by the superoxide anion radical on the $\mathrm{CH}_{2}-\mathrm{O}$ group. Additionally, this effect is supported by the $n$-propoxy group of the TE4 additive compared to the smaller methyl group. ${ }^{27}$

\section{Discharge product characterization}

FTIR and XPS were used to reveal the nature of the discharged product formed. Fig. 8 shows the IR spectra of the discharged cathode. The signal at $400-700 \mathrm{~cm}^{-1}$ indicates the presence of $\mathrm{Li}_{2} \mathrm{O}_{2}$, together with side products such as $\mathrm{Li}_{2} \mathrm{CO}_{3}$ at 1392$1570 \mathrm{~cm}^{-1}$. There is no strong indication that $\mathrm{LiOH}$ is present as the discharge product. The presence of a C-F signal at 1263-
$1141 \mathrm{~cm}^{-1}$ indicates that the PTFE binder utilized is stable during discharge in $\mathrm{Li}-\mathrm{O}_{2}$. Upon exposure to air for 15 minutes (Fig. S7†), the IR signal in the $1392-1570 \mathrm{~cm}^{-1}$ region and $869 \mathrm{~cm}^{-1}$ increases, indicating the presence of a discharged product that is unstable in air, likely to be $\mathrm{Li}_{2} \mathrm{O}_{2}$. To further confirm the chemistry of the discharged product, XPS analysis was done on the discharged cathode with and without the TE4 additive. Fig. 9 shows the XPS core level spectra of the pristine cathode and discharged cathodes with and without the TE4 additive. The O1s spectra of both discharged samples indicate the formation of $\mathrm{Li}_{2} \mathrm{O}_{2}$ at a binding energy of $531.5 \mathrm{eV}$, as well as, side products such as $-\mathrm{CO}_{3}, \mathrm{C}=\mathrm{O}, \mathrm{C}-\mathrm{O}$, and $\mathrm{O}-\mathrm{F}$ containing compounds at binding energies of 532.1, 533.5, and $534.3 \mathrm{eV}$, respectively. ${ }^{38,39} \mathrm{C} 1 \mathrm{~s}$, F1s, and Li1s spectra confirm the formation of such compounds, and in addition, F1s spectra show the formation of LiF on the discharged cathodes.

The presence of a peak with a very high binding energy at above $534 \mathrm{eV}$ in the $\mathrm{O} 1 \mathrm{~s}$ spectra suggests that $\mathrm{O}$ is bonded to highly electronegative elements such as F. This consequently resulted in the appearance of a peak with a very high binding energy, above $692 \mathrm{eV}$, in the F1s spectra. F-O containing compounds could, for example, be formed due to the decomposition of $\mathrm{LiPF}_{6}$ resulting in the appearance of a peak at above $534 \mathrm{eV}$, as reported in different literature studies. ${ }^{40,41}$ The presence of O-F in compounds at a high binding energy of $\sim 692$ $\mathrm{eV}$ in the F1s spectra and at above $534 \mathrm{eV}$ in the O1s spectra has also been reported in the literature, for example, the formation of the $\mathrm{Si}-\mathrm{O}-\mathrm{F}$ bond during the $\mathrm{SiO}_{2}$ etching process. ${ }^{\mathbf{4 2 - 4 4}}$

In order to understand the origin of the O-F signals formed, we deconvoluted and quantified the F1s spectra. The result is shown in Table 2.

We found that the quantity of the $\mathrm{O}-\mathrm{F}$ bond formed in the cathode discharged in the TEGDME electrolyte is similar to the one discharged in the TEGDME + TE4 additive. This indicates that the $\mathrm{O}-\mathrm{F}$ bond mostly originates from other F-containing compounds such as the LiTFSI salt, in agreement with the literature, showing that LiTFSI decomposed during discharge in Li-O ${ }_{2}$ batteries. ${ }^{45-49}$ LiTFSI, similar to the $\mathrm{LiPF}_{6}$, which decomposes to $\mathrm{Li}_{x} \mathrm{PF}_{y} \mathrm{O}_{z}$, may decompose to $\mathrm{O}$ and $\mathrm{F}$ containing

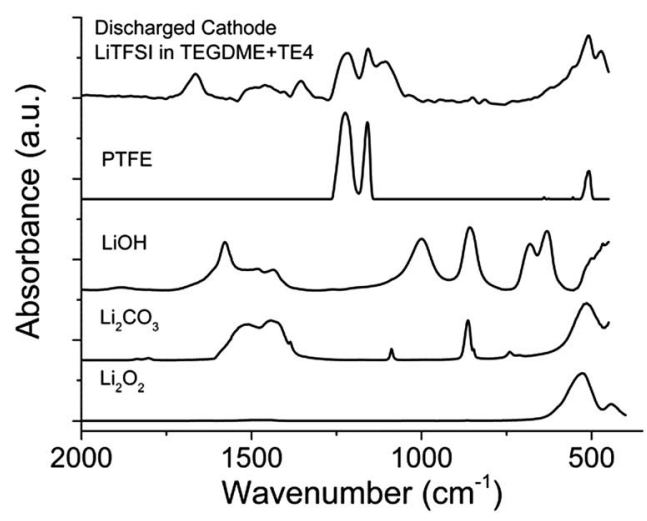

Fig. 8 FTIR spectra of the cathode discharged using $0.1 \mathrm{M}$ LiTFSI: TEGDME + 20 vol\% TE4 electrolyte at $100 \mathrm{~mA} \mathrm{gc}^{-1}$. Comparison of $\mathrm{LiOH}, \mathrm{Li}_{2} \mathrm{CO}_{3}, \mathrm{Li}_{2} \mathrm{O}_{2}$ and PTFE FTIR spectra is provided. 

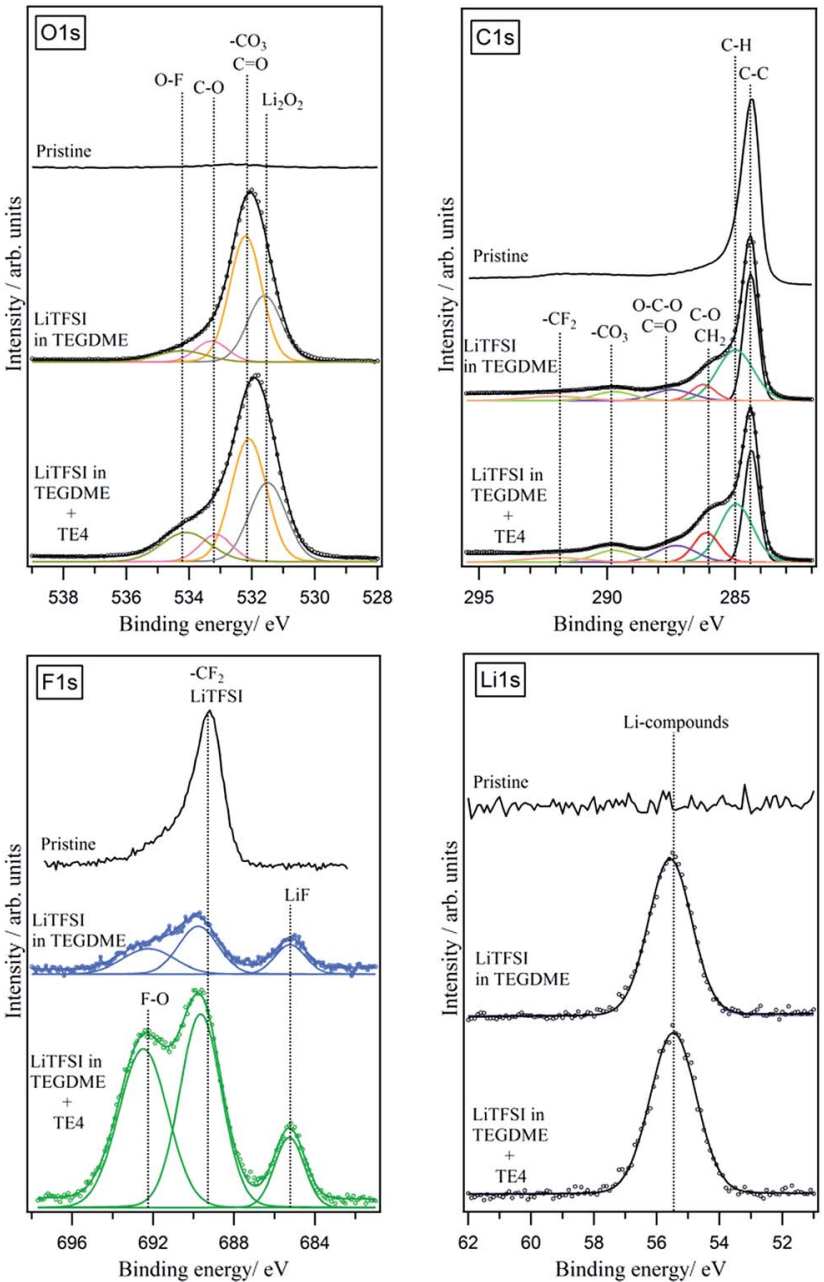

Fig. 9 XPS O1s, C1s, F1s, and Li1s spectra of pristine and discharged cathodes with and without the TE4 additive. The cathode was discharged at $100 \mathrm{~mA} \mathrm{gc}^{-1}$.

compounds. ${ }^{\mathbf{4 0 , 4 1 , 5 0}}$ The XPS results show that the TE4 addition does not result in additional discharge products from the parasitic reaction.

In summary, the spectroscopy data agrees with those of the TE4 additive, a $\gamma$-fluorinated ether, which has a good stability in Li- $\mathrm{O}_{2}$ batteries, considerably enhanced compared to an $\alpha$-fluorinated ether. The ${ }^{1} \mathrm{H}$ and ${ }^{19} \mathrm{~F}$ NMR results show that the additive is retained after discharge in the $\mathrm{Li}-\mathrm{O}_{2}$ battery and no additional product dissolved in the electrolyte is observed. FTIR and XPS data confirmed the formation of $\mathrm{Li}_{2} \mathrm{O}_{2}$ during discharge. Side products such as $-\mathrm{CO}_{3}, \mathrm{C}=\mathrm{O}, \mathrm{C}-\mathrm{O}$, and $\mathrm{O}-\mathrm{F}$ containing compounds and LiF are also detected, most likely

Table 2 Peak quantification for the deconvoluted F1s spectra

\begin{tabular}{llll}
\hline & & $\mathrm{CF}_{2}$ (PTFE) and & \\
Electrolyte & $\mathrm{LiF}$ & LiTFSI & F-O \\
\hline 0.1 M LiTFSI:TEGDME & $25 \%$ & $32 \%$ & $43 \%$ \\
0.1 M LiTFSI:TEGDME + TE4 & $25 \%$ & $35 \%$ & $40 \%$
\end{tabular}

from the LiTFSI salt and TEGDME decomposition. The decomposition of LiTFSI is supported by the change of the LiTFSI peak ratio in the ${ }^{19} \mathrm{~F}$ NMR result after discharge.

\section{Conclusions}

We showed the effect of the TE4 additive in enhancing the discharge performance of $\mathrm{Li}-\mathrm{O}_{2}$ batteries, which confirms the potential of utilizing dissolved fluorocarbon additives in this chemistry. The addition of 20 vol\% TE4 resulted in a discharge capacity of $400 \mathrm{~mA} \mathrm{~h} \mathrm{~g}_{\mathrm{C}}{ }^{-1}$ enhanced by a factor of 10 . To the best of our knowledge, this is the first time also that the $\mathrm{O}_{2}$ solubility and diffusion of the TE4 compound are reported.

The electrochemical performance improvement is related to enhanced $\mathrm{O}_{2}$ solubility and mass transport in the TEGDME solvent as evidenced by a pressure change measurement technique.

NMR analysis of the electrolyte before and after discharge showed the considerably enhanced TE4 chemical stability against superoxide radical attack during discharge, compared to the previous additive we reported. We also showed that $\mathrm{Li}_{2} \mathrm{O}_{2}$ is present after discharge and no additional product is detected from the parasitic reactions with the TE4 additive. These encouraging results are the first step in finding optimized additives especially for higher discharge rates, where not only the stability of such additives is required but also the fast $\mathrm{O}_{2}$ mass transport.

\section{Acknowledgements}

This research project is funded by the National Research Foundation Singapore under its Campus for Research Excellence and Technological Enterprise (CREATE) programme. We thank Solvay company for providing LiTFSI salt. P. H. thanks Fonds der Chemischen Industrie (FCI) for a Ph.D. scholarship. J. J. acknowledges support by the Laboratory of Materials Research (LaMa and ElCh).

\section{Notes and references}

1 M. Balaish, A. Kraytsberg and Y. Ein-Eli, ChemElectroChem, 2014, 1, 90.

2 S. S. Zhang and J. Read, J. Power Sources, 2011, 196, 2867.

3 A. Rinaldi, Y. Wang, K. S. Tan, O. Wijaya and R. Yazami, in Advances in Batteries for Medium and Large-Scale Energy Storage, ed. C. Menictas, M. Skyllas-Kazacos and T. M. Lim, Woodhead Publishing, Cambridge, 1st edn, 2014, pp. 419430.

4 Y. Wang, D. Zheng, X. Yang and D. Qu, Energy Environ. Sci., 2011, 4, 3697.

5 Y. Nishikami, T. Konishi, R. Omoda, Y. Aihara, K. Oyaizu and H. Nishide, J. Mater. Chem. A, 2015, 3, 10845.

6 S. S. Zhang, K. Xu and J. Read, J. Power Sources, 2011, 196, 3906.

7 J. Read, M. Ervin, W. Behl, J. Wolfenstine, A. Driedger, D. Fostera and K. Mutolo, J. Electrochem. Soc., 2003, 150, A1351. 
8 C. Xia, C. L. Bender, B. Bergner, K. Peppler and J. Janek, Electrochem. Commun., 2013, 26, 93.

9 J. G. Riess, Colloids Surf., A, 1994, 84, 33.

10 J. G. Riess, Chem. Rev., 2001, 101, 2797.

11 M. P. Krafft and J. G. Riess, Chapter 11: PerfluorochemicalBased Oxygen Therapeutics, Contrast Agents, and Beyond, in Fluorine Health, ed. A. Tressaud and G. Haufe, Elsevier, 2008.

12 J. Lu, L. Li, J.-B. Park, Y.-K. Sun, F. Wu and K. Amine, Chem. Rev., 2014, 114, 5611.

13 C. O. Laoire, S. Mukerjee, E. J. Plichta, M. A. Hendrickson and K. M. Abraham, J. Electrochem. Soc., 2011, 158, A302.

14 H.-G. Jung, J. Hassoun, J.-B. Park, Y.-K. Sun and B. Scrosati, Nat. Chem., 2012, 4, 579.

15 R. Battlno, T. R. Rettich and T. Tominaga, J. Phys. Chem. Ref. Data, 1983, 12, 163.

16 J. Read, K. Mutolo, M. Ervin, W. Behl, J. Wolfenstine, A. Driedger and D. Foster, J. Electrochem. Soc., 2003, 150, A1351.

17 R. Yazami, US Pat., 0266907 A1, 2010.

18 M. Balaish, A. Kraytsberg and Y. Ein-Eli, Phys. Chem. Chem. Phys., 2014, 16, 2801.

19 B. D. McCloskey, D. S. Bethune, R. M. Shelby, G. Girishkumar and A. C. Luntz, J. Phys. Chem. Lett., 2011, 2, 1161.

20 V. S. Bryantsev, V. Giordani, W. Walker, M. Blanco, S. Zecevic, K. Sasaki, J. Uddin, D. Addison and G. V. Chase, J. Phys. Chem. A, 2011, 115, 12399.

21 R. Black, S. Oh, J. Lee and T. Yim, J. Am. Chem. Soc., 2012, 134, 2902.

22 K. U. Schwenke, S. Meini, X. Wu, H. A. Gasteiger and M. Piana, Phys. Chem. Chem. Phys., 2013, 15, 11830.

23 K. R. Ryan, L. Trahey, B. J. Ingram and A. K. Burrell, J. Phys. Chem. C, 2012, 116, 19724.

24 S. A. Freunberger, Y. Chen, N. E. Drewett, L. J. Hardwick, F. Bardé and P. G. Bruce, Angew. Chem., Int. Ed., 2011, 50, 8609. 25 V. Bryantsev and M. Blanco, J. Phys. Chem. Lett., 2011, 2, 379.

26 S. A. Freunberger, Y. Chen, Z. Peng, J. M. Griffin, L. J. Hardwick, F. Bardé, P. Novák and P. G. Bruce, J. Am. Chem. Soc., 2011, 133, 8040.

27 V. S. Bryantsev, J. Uddin, V. Giordani, W. Walker, D. Addison and G. V. Chase, J. Electrochem. Soc., 2012, 160, A160.

28 D. D. Lawson, J. Moacanin, K. V. Scherer, T. F. Terranova and J. D. Ingham, J. Fluorine Chem., 1978, 12, 221.

29 Y. Marcus, Properties of Solvents, Wiley, New York, 1998.

30 EL-CELL GmbH, http:/www.el-cell.com/wp-content/ uploads/manuals/ECC_AIR_manual.pdf, accessed online May 2015.
31 K. U. Schwenke, M. Metzger, T. Restle, M. Piana and H. A. Gasteiger, J. Electrochem. Soc., 2015, 162, A573.

32 P. Hartmann, D. Grübl, H. Sommer, J. Janek, W. G. Bessler and P. Adelhelm, J. Phys. Chem. C, 2014, 118, 1461.

33 H. Ying and R. E. Baltus, Ind. Eng. Chem. Res., 2007, 46, 8166.

34 B. J. Bergner, A. Schu, K. Peppler, A. Garsuch and J. Janek, J. Am. Chem. Soc., 2014, 136, 15054.

35 S. A. Freunberger, Y. Chen, Z. Peng, J. M. Griffin, L. J. Hardwick, F. Bardé, P. Novák and P. G. Bruce, J. Am. Chem. Soc., 2011, 133, 8040.

36 J. Lu, L. Li, J.-B. Park, Y.-K. Sun, F. Wu and K. Amine, Chem. Rev., 2014, 114, 5611.

37 N. Madria, T. A. Arunkumar, N. G. Nair, A. Vadapalli, Y. W. Huang, S. C. Jones and V. P. Reddy, J. Power Sources, 2013, 234, 277.

38 R. Younesi, S. Urbonaite, K. Edström and M. Hahlin, J. Phys. Chem. C, 2012, 116, 20673.

39 R. Younesi, M. Hahlin and K. Edström, ACS Appl. Mater. Interfaces, 2013, 5, 1333.

$40 \mathrm{H}$. Bryngelsson, M. Stjerndahl, T. Gustafsson and K. Edström, J. Power Sources, 2007, 174, 970.

41 Y. C. Lu, A. N. Mansour, N. Yabuuchi and Y. Shao-Horn, Chem. Mater., 2009, 21, 4408.

42 J. S. Oh, J. B. Park, E. Gil and G. Y. Yeom, J. Phys. D: Appl. Phys., 2010, 43, 425207.

43 H. Park, K. Kwon, J. Lee, K. Suh, O. Kwon, K. Cho, H. Park, K. Kwon, K. Cho, S. Park and O. Kwon, Journal of Applied Physics, 1994, 4596, 4.

44 Y.-I. K. Hyung-Ho Park, K.-H. Kwon, S.-H. Lee, B.-H. Koak, S. Nahm, H.-T. Lee, K.-I. Cho and O.-J. Kwon, ETRI J., 1994, 16, 45.

45 G. M. Veith, J. Nanda, L. H. Delmau and N. J. Dudney, J. Phys. Chem. Lett., 2012, 3, 1242.

46 B. D. Mccloskey, A. Valery, A. C. Luntz, S. R. Gowda, G. M. Wallraff, J. M. Garcia, T. Mori and L. E. Krupp, J. Phys. Chem. Lett., 2013, 4, 2989.

47 E. Nasybulin, W. Xu, M. H. Engelhard, Z. Nie, S. D. Burton, L. Cosimbescu, M. E. Gross and J. Zhang, J. Phys. Chem. C, 2013, 117, 2635.

48 D. Sharon, V. Etacheri, A. Garsuch, M. Afri, A. A. Frimer and D. Aurbach, J. Phys. Chem. Lett., 2013, 4, 127.

49 R. Younesi, G. M. Veith, P. Johansson, K. Edström and T. Vegge, Energy Environ. Sci., 2015, 1905-1922.

50 R. A. Quinlan, Y.-C. Lu, Y. Shao-Horn and A. N. Mansour, J. Electrochem. Soc., 2013, 160, A669. 